Boston University School of Law

Scholarly Commons at Boston University School of Law

Faculty Scholarship

1988

Fairy Tales Surrogate Mothers Tell

George J. Annas

Follow this and additional works at: https://scholarship.law.bu.edu/faculty_scholarship

Part of the Health Law and Policy Commons 


\title{
Fairy Tales Surrogate Mothers Tell
}

\author{
George J. Annas
}

How did surrogate motherhood evolve from a "harebrained, fly by night" idea of the late 1970 into one that had at least some mainstream, middle-class support in the mid-1980s? Many explanations have been suggested. Although the rate of infertility has not increased, ${ }^{2}$ infertility is no longer a secret, and there are major public support groups, like RESOLVE, that advocate for infertile couples. New and powerful techniques like IVF (in vitro fertilization) have been developed, and although they help very few people, ${ }^{2}$ they have been widely publicized and approved. And babies are fashionable again. As one movie critic put it: "Men and women do not fall in love with each other in the movies anymore. They fall in love with babies. Babies are the new lovers-unpredictable, uncontrollable, impossible and irresistible."3

These explanations all have some merit. But the core of surrogate motherhood lies in the modern fairy tale that babies can properly be viewed as a consumer prod. uct for those with money to purchase them, and that by permitting this transaction we will all live happily ever after. As a product babies have been hyped by slick, white, middle-class professionals and advertised in the free-market environment of the 1980 . We are asked not to look behind the resulting children to see their lowermiddle-class and lower-class mothers. But the core reality of surrogate motherhood is that it is both classist and sexist: a method to obtain children genetically related to white males by exploiting poor women. While it is promoted as simply supplying babies for those who "desperately" want them, in fact it subverts any principled notion of economic fairness and justice, and undermines our commitment to equality and the inherently priceless value of human life.

We all have myths to comfort us when reality is

C 1988 George J. Annas unacceptable. Surrogate motherhood is just one such myth. But the myth of surrogate motherhood is no longer sustainable, and without its fairy tale veneer, surrogate motherhood, as we now know it, cannot long survive. This brief article will argue that the death of commercial surrogacy should not be mourned. Instead, our attention should turn to planning for the future, to avoid the commercialization of human embryos, the degradation of pregnancy, and the further exacerbation of class distinctions and economic violence that the use of embryos genetically unrelated to the "surrogate mothers" who bear them could bring.

\section{The Birth of "Surrogate Motherhood"}

Attorney Noel Keane, the self-proclaimed "father of surrogate motherhood," first got the idea when Jane and her husband Tom visited him in September 1976.4 Tom had "this harebrained idea of finding another woman to carry a child for them" (Jane was infertile) but didn't know how to go about it. He had ruled out adoption:

Maybe it's egotistical but I want my own child. Adoption leaves me cold. I guess for some women, as long as they have a child, it's fine. But for me, it's like if I see my child do something, I need to know that he's really mine. ${ }^{5}$

Tom had met Jane during the Vietnam War. He had seen a lot of men get killed, and told Keane:

[S]ay, if a woman had a couple of children and her husband was killed in the war, and, say, she needed a few extra dollars for the family, well, then maybe she could help someone out who couldn't have children. The Lord intended women to have children and I thought maybe one would want to do what came naturally and maybe help 
Volume 16: 1-2, Spring 1988

somebody else out while helping herself and her family. Like I say, it's just a fly-by-night idea I had. $^{6}$

Tom needed an attorney because he wanted anonymity; otherwise, he said, "I could just go out and look for a woman." While Keane was thinking it over, an article appeared in the San Francisco Chronicle about a man who had successfully advertised to find a woman to bear a child for him through artificial insemination. He had paid $\$ 7,000$ to the woman and another $\$ 3,000$ in legal and medical expenses. The child was born September 6,1976 . Shortly thereafter a medical newspaper reported the story, headlining it: " 'Surrogate Mother' Is Recruited by Ad for Artificial Insemination." Noel Keane made his decision: "I had never done as much as an adoption, but if they can do it in California, I thought, what the hell, we can do it here."7

Tom and Jane eventually made a deal with Carol to be inseminated. There was no fee involved, because Keane had been properly advised by a probate court judge that fees were illegal in Michigan. Carol, who was divorced, recalls making the decision with her three sons. "I told them what good parents Tom and Jane would be, and, from the start, we agreed we would call it Tom and Jane's baby, never mother's baby." 8 When Carol became pregnant, Jane recalls: "I wanted to put Carol under a glass bowl. You know, don't do this, don't do that. Are you eating right? Are you drinking enough? Are you taking your vitamins?"9 The contract that Tom and Jane signed with Noel Keane stated, explicitly, "[I]f a surrogate is found and is, in fact, inseminated, there is no assurance she will give up the child."10

Carol did give up the child. But Keane's first case illustrates most of the problems and pitfalls of so-called "surrogate motherhood" that remain unresolved more than a decade later: the use of fairy tale language, the commodification of children, and the degradation of pregnant women.

\section{The Reality Behind the Fairy Tales}

Fairy tale language is not unique to surrogate motherhood. In the past year alone we have witnessed glitzy TV evangelists preach that they must have our money because God has demanded it, national security advisers surreptitiously trading arms for Iran-held hostages in the name of democratic values, and insatiable stock manipulators using inside information for personal gain in the name of free enterprise. Touted as family building for infertile couples, surrogate motherhood stems from the same greed that threatens the best impulses and values in our society. The truth about surrogacy's "family building" is that it can create one parent-child relation- ship only by destroying another parent-child relationship. As Elizabeth Kane, the country's first openly paid "surrogate mother," put it recently, "[S]urrogate motherhood is nothing more than the transference of pain from one woman to another." " Even its strongest supporters freely admit that if they could not pay women a large fee for giving up their children, they would be out of business. And the brokers, like Noel Keane, usually charge at least as much for their own services (approximately $\$ 10,000)$ as they are willing to pay women to undertake a pregnancy and give up their child. Nor is it "just like adoption." Adoption seeks to find rearing parents for children without them; surrogacy seeks a child for would-be rearing parents. Adoption places the interests of the child first; surrogacy places the interests of the adults first. The exclusive use of this method by rich and upper-middle-class white couples proclaims its economic class and racial characteristics. For example, although black couples are twice as likely as white couples to be infertile, ${ }^{12}$ this method is not promoted for black couples, nor has anyone openly advocated covering the procedure by Medicaid for poor infertile couples.

The central deception, of course, is the name itself. The term "surrogate motherhood" seems purposely designed to dehumanize the mother and alienate her from her child. As Noel Keane put it in commenting favorably on the lower court Baby M decision, "She [the surrogate mother] has to realize she is carrying their child." 3 As the New Jersey Supreme Court noted simply and forcefully, in the Baby $M$ case, "the natural mother [is] inappropriately termed the 'surrogate mother.' "'14 Whenever we decide not to give something its rightful, descriptive name (in this case, "mother" or "birthmother"), it seems fair to assume that we are at least uncomfortable with the reality we are describing and want to believe some myth instead. In this case, the phrase "surrogate mother" actually comes from Harlow's monkey studies, in which newborn monkeys were separated from their mothers and placed in cages with a wire or a cloth-covered inanimate "surrogate mother" to test their responses. ${ }^{5}$ Indeed, this identification of the "surrogate mother" as inanimate object is often complete, the so-called surrogate mother being referred to simply as the "surrogate," and sometimes as a "surrogate womb" or a "surrogate uterus."

Finally, although an attempt is almost always made to conflate "surrogate motherhood" with new science and technology, and with "new reproductive techniques," in fact the only thing new about this method is the introduction of attomeys into human reproduction. And the lawyer's role itself is inherently deceptive. Drafting a contract all parties sign, the lawyer usually assures them that it is "not enforceable"-but nonetheless accepts a very large fee for his draftsmanship. It seems overtime to ask why it's not legal malpractice and 
fraud for attorneys to charge clients large fees to draft contracts they publicly describe as unenforceable. ${ }^{16}$ But, of course, it is not the role of contract-drafter that the lawyer actually plays-that's just another fairy tale for the adults. The lawyer's real role is that of procurer, obtaining a woman willing to bear a child for the couple and give it up to them upon birth. As Barbara Katz Rothman has noted, although debate on surrogate motherhood and prostitution continues among feminists, "There is virtual unanimity [among feminists] on the inappropriateness of other people selling our bodies." She goes on to term the brokers "the pimps" of the surrogacy business. ${ }^{17}$ Like all pimps, their main motivation is greed, and their primary concern about women is how much money they can make by using them.

The reality of "surrogate motherhood" is that a lawyer-broker agrees, for a fee, to locate a woman who will agree to be inseminated with the sperm of a man, have a baby, and for a fee, agree to give the child up to the father (or relinquish her parental rights to the child) upon birth. This is artificial insemination coupled with baby-selling. But what's wrong with baby-selling?

\section{Baby-Selling}

Baby-selling comes complete with its own fairy tale, the Grimms" "Rumpelstiltskin." Having agreed to give her first-born to Rumpelstiltskin if he would spin a roomful of straw into gold for her (a feat that helped make her queen), the queen changed her mind upon the birth of her son, and sought to get out of the contract. Rumpelstiltskin gave her a way out: three days to discover his name. Fortunately for her she did, and Rumpelstiltskin was so distressed to lose the child that "he tore himself in two." The Grimms' sympathy was obviously with the mother, even though she was rich, had entered into the contract voluntarily, and had profited greatly by it. So is the sympathy of most readers. But the baby brokers (and even some women) have argued that "a deal is a deal" and that the women-almost always poor women-who have agreed in advance to sell their babies at birth should be forced to go through with the deal so that the ability of women to enter contracts is not compromised.

Must we force women who change their minds to sell children they desperately want to raise in order to satisfy some unrealistic and nonlegal notion of specific performance? This is economic violence at its starkest and is properly labeled economic brutality. The simple answer might be that since we have outlawed the sale of human kidneys (and other organs) because of the degrading prospect of having the rich live off the body parts of the poor, it follows a fortiori that the sale of children should also be outlawed. If and when uterine transplants become feasible, it is doubtful we would (or should) permit fertile women to sell their uteruses to women who need them to become pregnant and give birth. But many would treat children with less respect than kidneys or uteruses, or at least are willing to permit fathers to buy the mother's interest in rearing the child from her and give that interest to their own wife. Should this be permitted? Sale was not involved in Carol's case, but was the key to the much more celebrated case of Mary Beth Whitehead (Baby $M$ ).

In that case, the New Jersey Supreme Court had no problem in concluding (as did the Michigan judge whom Noel Keane consulted more than a decade ago) that payment to place a child for adoption (even with the spouse of the child's father) violated the state's adoption laws. The court declared that "the evils of baby bartering are loathsome for a myriad of reasons." 18 There is coercion, lack of counseling, and exploitation of all parties (including desperate infertile couples), as well as the fact that "the child is sold without regard for whether the purchasers will be suitable parents"19 and the lack of any protection of the natural mother. Making money takes precedence even over predictable human suffering. For example, the broker in the Baby $M$ case failed to make further inquiry when a psychological evaluation of Ms. Whitehead revealed that she might change her mind. In the court's words: "It is apparent that the profit motive got the better of the Infertility Center.... To inquire further might have jeopardized the Infertility Center's fee." ${ }^{20}$

The selling of babies, which has been so slickly glazed over by others, properly disgusted the court. The court noted that the originator of this scheme to circumvent the law by private contract is "a middle man, propelled by profit" who "promotes the sale.... [T] he profit motive predominates, permeates, and ultimately governs the transaction." ") What's wrong with profit and using money as the sole measure of the value of children? The court did not hesitate to say:

There are, in a civilized society, some things that money cannot buy.... There are ... values that society deems more important than granting to wealth whatever it can buy, be it labor, love, or life. ${ }^{22}$

Not the least of these values is the protection of children from the vicious exploitation that treating them as commodities would bring, exploitation of the poor by the rich, and the demeaning of pregnant women by treating them as breeders indentured to their "employers."

There has been much confusion about constitutional rights in the surrogacy arrangement. The only real rights at stake are those involving the rights to custody of a child resulting from an unwed pregnancy, and in this 
contest the rights of the child properly take precedence. There is no constitutional right to purchase a child, even your own. And whatever "procreation" rights might be raised to a constitutional level in the area of custody, the rights of the mother must be at least as strong as those of the father. Indeed, they are stronger, since fertile men need a nine-month commitment on the part of a woman to procreate, whereas fertile women only need sperm to procreate.

The constitutional right to privacy is founded on liberty interests in intimacy and freedom of association, and notions of self-identity and self-expression. Privacy is not a technocrat's toy, and does not require the government to keep its hands off any method of procreation that inventors can devise. Treating men and women equally in the realm of noncoital reproduction may require that egg donation be treated like sperm donation; but no principled argument can equate (as the trial judge in Baby $M$ did) nine months of gestation and ultimate childbirth with sperm donation. As the U.S. Supreme Court has ruled, states cannot even permit husbands to prohibit their wives from having abortions, since, among other things, "it is the woman who physically bears the child and she is the more directly affected by the pregnancy." that husbands have no right to prevent their wives from becoming sterilized. In the court's words:

We have found no authority and the plaintiff has cited none which holds that the husband has a right to a childbearing wife as an incident to their marriage. We are neither prepared to create a right in the husband to have a fertile wife nor to allow recovery for damage to such a right. We find the right of the person who is capable of competent consent to control his own body paramount. ${ }^{24}$

If husbands have no constitutional right to fertile wives, it follows that they have no constitutional right to contract with unrelated women for purposes of reproducing themselves. Although the Baby $M$ court saved for another day the question of whether a woman can irrevocably waive her constitutional right to the companionship of her children by a pre-conception contract (assuming such a contract is "legalized" by future legislation), there would seem to be no basis that would allow the courts to enforce such an agreement. Even the lower courr Baby $M$ judge, for example, recognized that a woman could not irrevocably waive her right to terminate her pregnancy under the U.S. Constitution because judicial enforcement of such an agreement would be an intolerable burden on the woman. ${ }^{25}$ The argument against permitting an irrevocable prebirth waiver of maternal rearing rights seems at least as strong. Both decisions are so intimately related to the individual's personhood and human dignity that it would be an in- tolerable violation of personal integrity to force compliance with either. This is because pregnancy and childbirth may predictably and radically change self-image and self-fulfillment aspirations that are central features of identity and personhood.

The Baby $M$ court could have gone further. It did not, for example, even discuss the images of slavery inherent in enforcing contracts in commercial surrogate motherhood. Selling children conjures up the indignity and degradation of selling any human being; but more than that, specifically enforcing contracts that lead to the involuntary breakup of a family unit is at the heart of what many Americans found most repulsive about slavery prior to the Civil War. As James McPherson, one of the war's great historians, has noted: "This breakup of families was the largest chink in the armor of slavery's defenders."

McPherson tells us that one of the most powerful "moral attacks" on slavery was Theodore Weld's American Slavery as It Is. First published in 1839 , it was made up mainly of newspaper excerpts and advertisements. An example:

NEGROES FOR SALE-A Negro woman 24 years of age, and two children, one eight and the other three years. Said negroes will be sold separately or together as desired. ${ }^{27}$

He also notes that the influential Uncle Tom's Cabin was itself based on the forced breakup of the family: "Eliza fleeing across the ice-choked Ohio River to save her son from the slave-trader and Tom weeping for children left behind in Kentucky when he was sold South are among the most unforgettable scenes in American letters." seriously discuss the relevance of selling children and forcibly removing them from their mothers to one of the core aspects of nineteenth-century American slavery indicates our preference for dealing with fairy tale versions of surrogacy.

Since the sale of children can lead to their commodification or reification, ${ }^{29}$ and since this will devalue all children and put all children at risk, it is quite reasonable to outlaw the sale of children, even to their fathers. But if greed is the real root of evil, isn't surrogacy motivated by love rather than by money (as in the case of Carol) acceptable?

\section{The Degradation of Pregnancy}

Margaret Radin has noted that whether surrogacy is paid or unpaid it may still involve "ironic selfdeception." In her words:

Acting in ways that current gender ideology characterizes as empowering might actually be disem- 
powering. Surrogates may feel they are fulfilling their womanhood by producing babies for someone else, although they may actually be reinforcing oppressive gender roles. ${ }^{30}$

She goes on to note that would-be fathers can also be seen as oppressors of their wives, who, believing it is their duty to mother their husband's genetic child, "could be caught in the same kind of false consciousness and relative powerlessness as surrogates who feel called upon to produce children for others." ${ }^{\prime \prime}$

These arguments seem intuitively correct: another key to surrogate motherhood is the traditional (and oppressive) female role it reinforces. The male's right to have a child is seen as paramount, and any interest the mother might have in their child is subordinated to it-even though a male has no more right to have a child than he does to have a fertile wife or to prevent his wife from being sterilized or from having an abortion. Men simply don't have this power over women, and we do not advance sexual equality by promoting a scheme that subordinates females so completely to male interests.

The "surrogate mother" is asked not only to perform this "service" for the male, but also to engage in purposeful self-deception. Like Carol, she is asked to pretend that the child she is carrying is not her own, but only the father's. The country's most famous surrogate mother, Elizabeth Kane, told her fairy tale simply during her pregnancy: "It's not my baby, it's the father's. I'm just growing it for him."g2 Another has declared on national television: "Motherhood is not biological."39 Nor is the father's wife unaffected. As one infertile wife announced in support of surrogacy, "The most rewarding thing a woman can do is raise her husband's child." 34 The supposition that the women in surrogacy are involved in a "liberating" experience is akin to the supposition that selling one's kidney gives one the freedom to control one's body.

But surrogacy involves more than just fairy tale-like self-deception. It involves real degradation of the pregnant woman by proclaiming that the most important concern is not her welfare but that of the fetus she is carrying. And this is what makes this "harebrained" idea both so offensive and so potentially important symbolically for women. The lower court judge in the Baby $M$ case, for example, termed surrogacy a "viable vehicle" to help deliver a baby to the Sterns; and the Sterns' expert witness termed Ms. Whitehead simply a "surrogate uterus." 35 The contract Noel Keane drafted, and which she signed, gave rights over her activities and body during the pregnancy to the father (William Stern), who could not only require that she undergo amniocentesis but also that she abort a handicapped child at his demand. If she refused, his contract obligations ended. ${ }^{36}$

This untenable proposition-that a pregnant wom- an's life is not her own but, rather, that others should be able to determine her activities based on what they think is in the best interests of the fetus she is carrying-underlies surrogacy. The contract attempts to get the mother to fantasize that she is simply a container carrying a precious cargo that she dare not injure. Since surrogacy does not take place in a vacuum, other physicians and courts have adopted the view that pregnancy is just for the fetus, and have ordered women to submit to Cesarean sections for the sake of their fetuses. ${ }^{37}$ In one outrageous case (since vacated), a court even ordered a dying woman to undergo emergency surgery against her will, to deliver a fetus that was of questionable viability..$^{8} \mathrm{I}$ have argued elsewhere that these cases were wrongly decided. ${ }^{39}$ But they are consistent with the notion that pregnant women are not fully human and can properly be viewed as containers; and it is of at least passing interest that even the Baby $M$ court cited the worst of these cases with apparent approval.4\%

The New Jersey Supreme Court is on solid ground in holding that surrogate mother contracts can never be specifically enforceable and that women must have the right to change their minds and assert their maternal rights to rear their children, at least up to the time after birth provided by the state's adoption statute.4" The New Jersey Supreme Court also seems correct in decreeing that when the woman does assert her maternal rights, she should retain custody during the legal battle over permanent custody, a decision that ultimately must be based on the best interests of the child. ${ }^{2}$ Arguing that we should try to prevent such custody battles by contract is tangential: the way to prevent them entirely is simply not to engage in this type of arrangement. Objecting to making decisions after birth in the child's best interests, and ignoring the interests of the child before birth, simply exposes the fact that the surrogacy arrangement never considers the child's welfare, only the welfare of the contracting parents. Nor is the argument that the child is always better off existing than not existing sufficient to justify surrogacy from the child's perspective. ${ }^{43}$ Unconceived children have no "right to exist," and we do not harm them by not conceiving them or by prohibiting such practices as polygamy. We do, however, harm real children by commodifying them, forceably separating them from their natural mothers, and setting up situations that predictably lead to unstable and uncertain family relationships.

\section{What Should Be Done?}

I understand those who would prohibit not just commercial surrogacy, but voluntary surrogacy as well. But just as we permit organ donations among living family members, we may also wish to permit relatives (especially sisters) to have children for each other. My own 
preference is for legislation aimed at what has been mistermed "full surrogacy," the hiring of a woman to carry a fetus to whom she is not genetically related. This will involve "high tech" IVF and embryo transfer (and probably freezing), and could become more popular since the resulting child will be the genetic child of both the husband and wife (assuming they supply the gametes). Use of this technology could much more radically alter our notions of pregnancy and motherhood.

To prevent the gross exploitation of poor women, to prevent pregnant women from being viewed simply as vessels, to recognize the greater contribution of gestation to the child, and to ensure that the child is protected by having at least one parent with responsibility for it available at birth, the gestational mother should be irrebuttably considered the rearing mother for all legal purposes. She could give the child up to the genetic mother and father after birth, but only by acting in conformity with the state's adoption laws. Permitting the gestational presumption to be modified by contract would make all pregnancies and all births suspect. No one would know who the newborn's "mother" was until contracts were examined and genetic testing performed. This "suspended motherhood" model is (or should be) societally insupportable, since it endangers all mothers and children. A statute that irrebuttably presumes the gestational mother to be the child's legal mother for all purposes would protect both mothers and children, and should be enacted in all states. ${ }^{44}$

The second statute I endorse is one that would outlaw the sale of human embryos. A few states have already enacted legislation to do this. Embryo freezing is just beginning in the U.S., but it will not be long before it is commonplace. The attempted commercialization and sale of frozen embryos will not be far behind. Like children, embryos will be bought and sold in the belief that they will produce a healthy child, and probably one of a certain physical type, IQ, stature, and so on. All of these characteristics will command a specific market price-thereby monetizing the characteristics of all live children. ${ }^{45}$ Because of this, and the fact that selling human embryos brings with it almost all of the problems and evils of selling children, their sale should be prohibited by stature. ${ }^{6}$

Commercial "surrogate motherhood" deserves the death without dignity that Rumpelstiltskin suffered. Legislation to try to resuscitate it and put it on temporary life-support systems would not be in the best interests of children, families, or society. But it has given us the opportunity to anticipate and plan for the next generation of issues brought to us by real science. W/e should act now to support economic and sexual equality, and to protect future children and families from commercial exploitation. We should work for a future in which pregnant women retain their personhood, a future of economic and social justice, rather than a future based on economic violence and social inequality. The fairy tales surrogate mothers tell must not be taken seriously.

\section{References}

1. G. John et al., "Infertile or Childless by Choice? A Multipractice Survey of Women Aged 35 and 5o," British Medical Journal, 294 (1987): 804; W.D. Mosher and W.F. Pratt, "Fecundity and Infertility in the United States, 1965-82," NCHS Advance Data, 104 (Feb. 11, 1985): 1; Mosher, "Reproductive Impairments in the United States, 1965-82," Demography, 22 (1985): 415; C.P. West, "Age and Infertility," British Medical Joumal, 294 (1987): 853; J. Menken, J. Trussell, and U. Larsen, "Age and Infertility," Science, 293 (1986): 1389 .

2. There have been fewer than 2,000 IVF births in the U.S. to date, compared with more than 4 million U.S. births annually.

3. D. Ephron. "In This Year's Movies Baby Knows Best," New York Times, March 19, 1988, A8\&L sec., p. 1. See also A. Kohn, "Parenthood Pabulum,"Psychology Today (July/Aug. 1988): $64-65$.

4. N. Keane and D. Breo, The Surrogate Mother (New York: Everest House, 1981), 27.

5. Id.: 29-30. Emphasis added.

6. Id.: 3o. Emphasis added.

7. Id.: 37.

8. Id.: 79. Emphasis added.

9. Id.: 82. Emphasis added.

10. Id.: 53 .

11. E. Kane, Birthmother (New York: Harcourt Brace Jovanovich, 1988), 275. And see $P$. Chesler, "What Is a Mother?," Ms., May 1988, 26-39.

12. S. Aral and W. Cates, "The Increasing Concern with Infertility: Why Now?," Journal of the American Medical Association, $850(1989)$ : 2327.

13. J. Barron, "Views on Surrogacy Harden After Baby M Ruling;" New York Times, April 2, 1987, Sec. B2, p. 1. Emphasis added.

14. In the Matter of Baby M, 537 A.2d 1227, 1234 (N.J. 1988).

15. H.F. Harlow, "The Nature of Love," American Psychologist, 18 (1958): 673; Harlow, N.C. Blazek, and G.E. McClearn, "Manipulative Motivation in the Infant Rhesus Monkey," Joumal of Comparative Pbysiology o Psychology, 14 (1956): 44 .

16. G.J. Annas, "Death Without Dignity for Commercial Surrogacy," Hastings Center Report, 18, 2 (April/May 1988): 21, 29.

17. 1. Peterson, "Feminists See Unfair Maternal Norm in Baby M Case," New York Times, March 20, 1987, at 18.

18. Baby $M$, supra note 14 , at 1241 . And see Surrogate Parenting Assoc. v. Kentucky, 704 S.W.2d 209 (Ky. 1986) (dissenting opinion).

19. Id.

20. Id.: 1247 .

21. Id.: 1249 .

22. Id.

23. Planned Parenthood of Central Missouri v. Danforth, 428 U.S. $5^{2}(1976)$.

24. Murray v. Vandevander, 522 P.2d 302, 304 (Okla. App. 1974). 
25. G.J. Annas, "Baby M: Babies (and Justice) for Sale," Hastings Center Report, 17, 3 (June 1987): 12, discussing In the Matter of Baby M, 217 N.J. Super. 313, 525 A.2d 1128 (1987).

26. J.M. McPherson, Battle Cry of Freedom: The Civil War Era (New York: Oxford University Press, 1988), $3^{8 .}$

27. Id.

28. Id. $38-39$. For a modem retrospective on how slavery destroyed families, see Toni Morrison's Pulitzer Prizewinning Beloved (New York: Knopf, 1987).

29. See M.J. Radin, "Market-Inalienability," Harvard Law Review, 100 (1987): 1849.

3o. Id.: $193^{\circ}$.

31. Id.: 1931; and see G. Corea, The Mother Machine (New York: Harper \& Row, 1985), 221-24.

32. Ms. Kane has since repudiated her role. See Kane, supra note 11 .

33. Geraldo, "The Happy Surrogates," aired Sept. 29, 1987 .

34. Id.

35. Baby $M$, supra note 25 .

36. Baby $M$, supra note 14, at 1268 (contract clause 13).

37. V.E.B. Kolder, J, Gallagher, M.T. Parsons, "Court-

Ordered Obstetrical Interventions," New England Journal of

Medicine, $366(1987): 1192$. And see Note, "Marernal Rights and Fetal Wrongs: The Case Against the Criminalization of 'Fetal Abuse," " Harvard Law Review, 101 (1988): 994.

38. In re A.C., 533 A.2d 611 (D.C. App. 1987), vacated
539 A. 2 d 203 (D.C. App. 1988). And see G.J. Annas, "She's Going to Die: The Case of Angela C.," Hastings Center Report, 18, 1 (Feb./March 1988): 23-25.

39. G.J. Annas, "Protecting the Liberty of Pregnant Patients," New England Joumal of Medicine, 316 (1987): 1213 ; and G.J. Annas, Judging Medicine (Clifton, N.J., 1988), $119-25$.

40. Baby $M$, supra note 14 , at $1254, n$. 13 . The entire note 13 is irrelevant to the Baby $M$ opinion itself, and is seriously flawed as a matter of constitutional analysis.

41. Id.: 1244-46. See also S. Wolf, "Enforcing Surrogate Motherhood Agreements: The Trouble with Specific Performance," NYLS Human Rights Annual, 4 (1987): 375 .

42. Baby $M$, supra note 14 , at $1257-61$.

43. See, e.g., J. Robertson, "Embryos, Families, and Procreative Liberty: The Legal Structure of the New Reproduction," Southem California Law Review, 59 (1986): 939, 9951000.

44. S. Elias and G.J. Annas, Reproductive Genetics and the Law (Chicago: Yearbook Medical Publishers, 1987). On the centrality of birth to motherhood, see K.A. Rabuzzi, Motberself: A Mythic Analysis of Motherhood (Bloomington: Indiana University Press, 1988).

45. Cf. Radin, supra note 29 , at $1925-26$.

46. G.J. Annas, "Making Babies Without Sex: The Law and the Profits," American Joumal of Public Health, 74 (1984): 1415, 1417. 